\title{
True Hermaphroditism presenting as an Inguinal Hernia
}

\author{
Kadir Ceylan, Ekrem Algun, Mustafa Gunes, Hasan Gonulalan \\ Yuzuncu Yil University, Faculty of Medicine, Departments of Urology and Endocrinology, Van, \\ Turkey
}

\begin{abstract}
A 21-year-old patient with cryptorchidism was found to have a left inguinal mass on physical examination. The patient was operated with a diagnosis of bilateral cryptorchidism and left inguinal hernia. Besides bilateral inguinal undescended testicles, female genital organs like fallopian tubes, uterus and ovary were found on the exploration.
\end{abstract}

Key words: cryptorchidism; inguinal hernia; urogenital abnormalities; true hermaphroditism Int Braz, J Urol. 2007; 33: 72-3

\section{INTRODUCTION}

In true hermaphroditism, both ovarian and testicular tissues are present in one or both gonads. Differentiation of the internal and external genitalia is highly variable. The external genitalia may simulate those of a male or female, but most often, they are ambiguous (1). The incidence is unknown, but more than 400 cases have been reported to this date. To justify the diagnosis, there must be histological documentation of both types of gonadal epithelium (2). The condition is usually diagnosed in the first few years of life (3). Here, we report a patient who first presented with bilateral cryptorchidism and left inguinal hernia when he was 21 years old.

\section{CASE REPORT}

A 21-year-old male patient presented with bilateral cryptorchidism and a mass in the left inguinal canal. He had a male phenotype with fully developed secondary sex characteristics. There were no hypospadias, gynecomastia or any other somatic anomaly. He presented normal morning erection and ejaculation and no history of urethral bleeding. Testes were palpable on physical examination in the inguinal canal. Ultrasound examination revealed bilateral cryptorchidism and left inguinal hernia. Serum testosterone, LH and FSH levels were within normal limits for an adult male and he had azoospermia on semen analysis. He was operated with a diagnosis of bilateral cryptorchidism and left inguinal hernia. On inguinal exploration bilateral cryptorchidism and uterus were found as well as fallopian tubes and ovary on the left inguinal canal. Thus, there were 3 separate gonads: one testis in the right side and one testis plus one ovary in the left side. Right testis orchiopexy was performed. Left testis and the female genital duct remnants were excised (Figure-1). Pathological examination of the testicular specimen revealed germinal aplasia of the testicular tissue. Unfortunately, karyotype analysis could not be performed for technical insufficiency. 


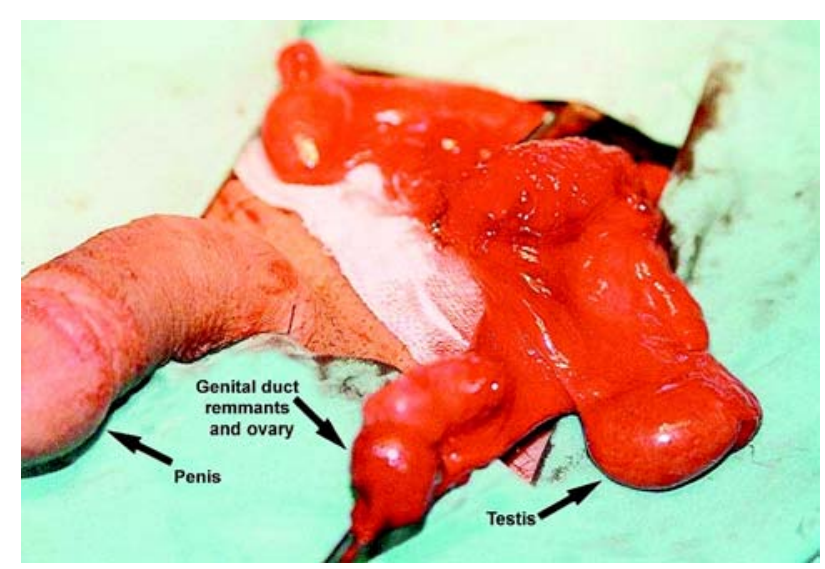

Figure 1 - Intraoperative view of the female genital duct remnants, ovary and testis.

\section{COMMENTS}

True hermaphroditism is a phenotypically and genetically an heterogeneous condition. Gonadal tissue may be located at any level along the route of embryonic testicular descent and is frequently associated with an inguinal hernia. There may be unilateral or bilateral ovotestis or a testis on one side and ovary on the other side. A uterus is usually present, though it may be hypoplastic or unicornous (1-4). Our case had testis on the right side and a testis and female genital structures on the left side. Ovarian tissue was dysgenetic and testicular tissue showed germinal aplasia.

In true hermaphroditism, the degree of virilisation of the external genitalia depends on the capacity of testicular tissue to secrete testosterone and the presence or absence of a uterus and tubes. Although approximately $70 \%$ of true hermaphrodites are raised as males, less than $10 \%$ have normal male external genitalia $(1,2)$. Our case had completely normal external genitalia except for cryptorchidism, moreover, the patient had fully developed secondary sexual characteristics and defined erections and ejaculations.

Most of the true hermaphrodites have ambiguous genitalia and are diagnosed in the first few months to years of their life (3). Our case is unique because there is no diagnosis during the first 21 years of his life.
True hermaphroditism should also be considered in the differential diagnosis of cryptorchidism and inguinal hernia in a patient in the second or third decade.

\section{CONFLICT OF INTEREST}

None declared.

\section{REFERENCES}

1. Conte FA, Grumbach MM: Abnormalities of Sexual Determination and Differentiation. In: Tanagho EA, McAninch JW (eds.), Smith's General Urology. International Edition, 15th ed., New York, McGrawHill. 2000; pp. 699-736.

2. Griffin JE, Wilson JD: Disorders of Sexual Differentiation. In: Walsh PC, Retik BA, Stamey TA, Vaughan DE (eds.), Campbell's Urology. Philadelphia, WB Saunders. 1992; pp. 1509-42.

3. Hadjiathanasiou CG, Brauner R, Lortat-Jacob S, Nivot S, Jaubert F, Fellous M, et al.: True hermaphroditism: genetic variants and clinical management. J Pediatr. 1994; 125: 738-44.

4. Diamond DA: Sexual Differentiation: Normal and Abnormal. In: Walsh PC, Retik BA, Vaughan DE, Wein AJ (eds.), Campbell's Urology. Philadelphia, WB Saunders. 2002; pp. 2395-427.

$\overline{\text { Accepted after revision: }}$

October 15, 2006 